\title{
Stav antropometrických parametrov a telesného zloženia u detí mladšieho školského veku
}

\section{The state of anthropometric parameters and body composition in children of younger school age}

\author{
Tomáš Hadžega, Václav Bunc \\ Fakulta tělesné výchovy a sportu, Univerzita Karlova v Praze
}

\begin{abstract}
Abstrakt
Cielom nášho sledovania bolo meranie vybraných antropometrických charakteristík a analýza aktuálneho telesného zloženia u detí mladšieho školského veku zo základných škôl v Prahe. Súbor tvorilo celkovo 222 probandov, chlapci (n-117) a dievčatá (n-105) vo veku 8-11 rokov (priemerný vek chlapci $=9,0 \pm 1,0$ rokov, telesná výška $=139,9 \pm 8,6 \mathrm{~cm}$, telesná hmotnost' $=32 \pm 7,5 \mathrm{~kg}, \mathrm{BMI}=$ $\left.16,3 \pm 2,4 \mathrm{~kg} \cdot \mathrm{m}^{-2}\right)$. Priemerný vek dievčatá $=8,9 \pm 0,9$ rokov, telesná výška $=137,3 \pm 8,8 \mathrm{~cm}$, telesná hmotnost' $=30,5 \pm 7,3 \mathrm{~kg}, B M \mathrm{I}=15,9 \pm 2,4 \mathrm{~kg} \cdot \mathrm{m}^{-2}$ ). Kanalýze telesného zloženia bol použitý multifrekvenčný prístroj BIA $2000 \mathrm{M}$ (celotelová bioimpedančná analýza). Deti mladšieho školského veku vykazovali vyššie hodnoty TBW - celkovej telesnej vody (chlapci 65,5 $\pm 6,0 \%$, dievčatá $66,6 \pm 6,5 \%$ ) nízke zastúpenie telesného tuku (chlapci 16,1 $\pm 2,4 \%$, dievčatá 16,5 22,9\%) a vyššie hodnoty koeficientu ECM/

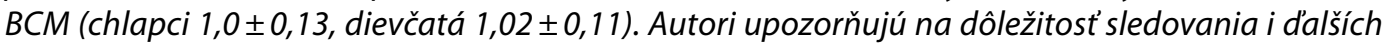
parametrov telesného zloženia, ako je napr. podiel beztukovej hmoty (FFM) a podiel segmentálneho rozloženia telesného tuku i svalovej hmoty na jednotlivých častiach ludského tela, ktoré je možné s úspechom využit 'k hodnoteniu efektu pohybovej intervencie.
\end{abstract}

\begin{abstract}
The aim of our observation was to measure selected anthropometric characteristics and to analyze actual body composition in children of younger school age from elementary schools in Prague. The group consisted of a total of 222 probands, boys $(n-117)$ and girls $(n-105)$ aged $8-11$ years (average boys age $=9.0 \pm 1.0$ years, body height $=139.9 \pm 8.6 \mathrm{~cm}$, body weight $=32 \pm 7.5 \mathrm{~kg}, B M I=16.3 \pm 2.4 \mathrm{~kg} \cdot \mathrm{m}^{-2}$ ). Average age girls $=8.9 \pm 0.9$ years, body height $=137.3 \pm 8.8 \mathrm{~cm}$, body weight $=30.5 \pm 7.3 \mathrm{~kg}, \mathrm{BMI}=$ $15.9 \pm 2.4 \mathrm{~kg} \cdot \mathrm{m}^{-2}$ ). The BIA $2000 \mathrm{M}$ multi-frequency apparatus (whole-body bioimpedance analysis) was used to analyze the body composition.

Children of younger school age showed higher TBW values - total body water (boys $65.5 \pm 6.0 \%$, girls 66.6 $\pm 6.5 \%$ ), low body fat (boys $16.1 \pm 2.4 \%$, girls $16.5 \pm 2.9 \%$ ) and higher ECM/BCM coefficients (boys $1.0 \pm 0.13$, girls $1.02 \pm 0.11$ ).

The authors draws, attention to the importance of monitoring other body composition parameters. The percentage of fat-free mass (FFM) and the share of segmental distribution of body fat and muscle mass on individual parts of the human body.
\end{abstract}

Klúčové slová: antropometria, bioelektrická impedancia, telesné zloženie, mladší školský vek.

Key words: anthropometry, bioelectrical impedance, body composition, younger school age. 


\section{ÚVOD}

Súčasný životný štýl väčšiny populácie sa vyznačuje nedostatkom pohybu a sedavým spôsobom života. Tento stav má za následok zvýšený výskyt civilizačných ochorení (napr. diabetes 2. typu alebo kardiovaskulárne problémy). Tieto ochorenia sú spojená hlavne s vysokým výskytom nadváhy a obezity v populácii. Tento problém sa však už netýka iba dospelých, ale rovnako tak aj detí. Podla WHO (2016) sa nadváha a obezita definuje ako nadmerné nahromadenie tukového tkaniva v luudskom tele. Primárnou príčinou je tzv. energetická bilancia, ktorá popisuje pomer príjmu a výdaju energie. Brettschneider a Naul (2007) uvádzajú, že príjem energie zo stravy v posledných dvoch dekádach stagnuje, zatial' čo sa priemerný výdaj energie v Európe významne znižuje. Zvýšené hodnoty telesného tuku v l'udskom tele majú negatívny vplyv na zdravie a telesnú zdatnost človeka. Podl'a autorov Měkota a Novosad (2005) je telesná zdatnost' kvalitatívny ukazovatel' stavu organizmu a jeho zdravia, ktorý má svoj fyziologický základ predovšetkým v zdatnosti kardiorespiračnej sústavy.

Jedným z ukazovatel’ov úrovne telesnej zdatnosti je telesné zloženie. Podl’a Malá a kol. (2009) sa zistovanie telesného zloženia stáva významnou súčastou vyšetrenia telesnej zdatnosti organizmu. Využiva sa pri vyšetrení bežnej populácie, ale aj u vrcholových športovcov alebo v niektorých profesiách (napr. vojaci či kozmonauti) k zistovaniu predispozície pre výkon. Rovnako tak sa využíva vo vztahu k výžive, ontogénzii či pri vyšetrení kardiovaskulárnych chorôb, obezity alebo podvýživy. Podl’a Suchomela (2006) má telesné zloženie v prípade výskytu nadmerného množstva telesného tuku samo negatívny vztah k ostatným zložkám telesnej zdatnosti, najmä k aeróbnej zdatnosti. Udržovanie zodpovedajúceho telesného zloženia je dôležité z hladiska prevencie vzrastajúceho výskytu obezity.

Momentálny problém obezity vo svete je považovaný za alarmujúci. Podla výskumov skracuje obezita život človeka približne o 7 rokov. Samotná obezita sa negatívne prejaví na telesnej zdatnosti človeka tým spôsobom, že jeho život skráti o d’alšie 2 roky (Bouchard, 2010). Dôležitou skutočnostou je pochopenie, že rodina v ktorej je jeden rodič obézny má dieta až $50 \%$ predpoklad, že v budúcnosti bude trpiet rovnakým problémom (Bouchard, 2010). Telesné zloženie je taktiež možné využit k posúdeniu životného štýlu i kvality života. Z hl'adiska ontogenézy je potrebné počitat s významnými rozdielmi v parametroch telesného zloženia u detí od veku cca 11-12 rokov, teda v období puberty. Podl'a Bunca (2007) je potrebné rešpektovat skutočnost’ posledných desatročí, kedy sa objavuje nový fenomén stagnácie alebo dokonca nárastu telesného tuku v období puberty u chlapcov i u dievčat. Údaj o rastúcom výskyte detí s nadváhou alebo obezitou v súvislosti s rastúcim vekom zodpovedá rovnako tak, údajom zo zahraničnej literatúry (napr. Brettschneider, Naul, 2007; Malina, Bouchard, 1991; Roche et al. 1996).

Obecne môžeme parametre telesného zloženia stanovovat množstvom metód, ktoré sa líšia ako prístrojovou a personálnou náročnostou, tak aj presnostou stanovenia sledovaných dát (Roche et al., 1996). Základný problém spočíva v predikčnej rovnici, ktorá $\mathrm{z}$ nameranej fyzikálnej veličiny určuje požadované parametre. Rovnica je závislá nielen na pohlaví a veku, ale aj na distribúcii telesného tuku (nepriamo na trénovanosti). Neexistuje obecná predikčná rovnica, preto neexistuje obecne použitel’ná metóda stanovenia telesného zloženia (Bunc, 2010). Novšie metódy hodnotenia telesného zloženia umožňujú určit nielen množstvo telesného tuku a beztukovú hmotu, ale dokážu súčasne posúdit aj “kvalitu” svalovej hmoty (Bunc a Štilec 2007, Heyward a Wagner 2004). Túto kvalitu je potom možné hodnotit pomocou molekulárneho modelu telesného zloženia.

Rozhodujúca je vel'kost' koeficientu ECM/BCM.

Koeficient ECM/BCM vyjadruje dôležitý parameter pre hodnotenie stavu výživy jedinca. Optimálny stav výživy zodpovedá hodnote koeficientu 0,7-0,8. Čím je koeficient nižší, tím väčšie množstvo beztukovej hmoty využitel’né pre pohybovou aktivitu jedinec má. Muži majú tento po- 
diel nižší než ženy. Podobne trénovaní jedinci disponujú nižšou hodnotou tohto koeficientu než netrénovaní. Ked' dosahuje koeficient hodnoty > 1,0 je využitel'nost beztukovej hmoty pre svalovú prácu nízka (Riegerová, Přidalová, Ulbrichová, 2006). Pomocou tohto koeficientu môžeme taktiež charakterizovat biologický vek a rovnako tak je možné hodnotit efekt pohybového režimu, ktorý bol aplikovaný u daného jedinca (Bunc, 2008). Pre tieto účely sa ukazuje ako vhodné využit metódu celotelovej bioimpedančnej analýzy za predpokladu použitia zodpovedajúcich predikčných rovníc.

V praxi existuje vel'ké množstvo jednoduchých meratel'ných ukazovatel'ov (BMI, obvod, pásu, obvod bokov, WHR atd’.), ktoré je možné použit pre posúdenie aktuálneho telesného stavu jedinca. Bohužial' použitie týchto ukazovatel’ov a ich interpretácia $v$ praxi je v mnohých prípadoch sporná. Vel'mi známym kvantitatívnym, klinickým ukazovatel’om zloženia tela je BMI (Body mass index). Použitie BMI u jednej osoby je však často zavádzajúce, pretože hodnotí iba celkovú hmotnost' a nie množstvo telesného tuku, ktoré je pre hodnotenie nadváhy alebo obezity rozhodujúce (Bunc, 2010). BMI síce dokáže zhodnotit či daný jedinec hmotnostne zodpovedá populačným normám, nedokáže však určit podiel jednotlivých komponentov a to predovšetkým v zmysle množstva telesného tuku a beztukovej hmoty, množstva celkovej telesnej vody a ich jednotlivých frakcií apod., prípadne segmentálne rozloženie týchto komponentov (Andreoli et al., 2003). V praxi si preto nevystačíme už s iba stanovením telesnej hmotnosti, ale je potrebné stanovit množstvo telesného tuku a d’alších prípadoch je nevyhnutné stanovit aj d’alšie premenné, ktoré sú zahrnuté pod pojmom telesné zloženie (Bunc, 2010). Súčasné zložitejšie a podrobnejšie metodiky, ktoré hodnotia telesné zloženie sa vzájomne líšia nielen prístrojovou a personálnou náročnostou, ale aj možnostami interpretácie a presnosti sledovaných dát, čo sú najvýznamnejšie faktory limitujúce ich použitie v rôznych podmienkach (Dlouhá a kol., 1998; Bunc, 2007b).

Znalost aktuálneho telesného zloženia okrem iného môže taktiež prispiet k posúdeniu zdravotného stavu jedinca, k posúdeniu jeho fyzickej pripravenosti, ale môže byt zohl’adnená i napríklad pri tvorbe odpovedajúcich cvičebných programov pre deti mladšieho školského veku. Bunc (2010) uvádza, že aktuálne telesné zloženie je dôsledkom genetických dispozícií, diétneho a pohybového režimu hodnoteného jedinca. Pravidelný pohybový režim v súčasnosti nachádzame zhruba iba u 16-18\% populácie (Bunc, 2007a). V prípade nízkeho objemu pohybovej aktivity dochádza k zvýšeniu percenta telesného tuku a naopak. Tento vztah je možné vyjadrit jednoduchým spôsobom tzv. energetickou bilanciou.

$$
\Delta E=E \text { prijem }-E \text { výdaj }
$$

Podla Konopku (2004) je dôležité, aby denný príjem energie bol v rovnováhe s energiou, ktorú dokáže človek každý deň vydat. V prípade, že k tejto rovnováhe nedochádza, výsledkom je nadváha až obezita daného jedinca. Bunc (2010) uvádza, že základnou príčinou nadváhy alebo obezity je práve neprispôsobenie príjmu energie jej výdaju.

Stav nadváhy alebo obezity má taktiež negatívny dopad na zdatnost̉ jedinca. Vzhl'adom na to, že pohyb je predpokladom zdatnosti jeho nedostatok vedie k zníženiu jej úrovne. Samotný pohyb je základná l'udská potreba a o jej nedostatku nemá organizmus aktuálnu, relevantnú informáciu.

Ked' táto potreba pohybu nie je kultivovaná s rastúcom vekom zaniká (Bunc, 2004).

Telesná zdatnost je podl’a Malinu et al. (2004) chápaná ako stav organizmu človeka umožňujúci mu vykonávat dennú činnost bez neprimeranej únavy a s dostatočnou rezervou pre príjemné strávenie vol’ného času. Bunc (2008) definuje zdatnost’ ako schopnost’ odolávat vonkajšiemu stresu a rovnako tak súbor predpokladov pre konkrétnu pohybovú činnost'.

Aktuálna zdatnost je určovaná geneticky a doterajším správaním alebo tréningom. Podl'a Bunca (2010) je aktuálne telesné zloženie dôsledkom genetických dispozícií, diétneho a pohy- 
bového režimu hodnoteného jedinca. Telesné zloženie je okrem genetických dispozícií taktiež výsledkom stravovacieho a pohybového režimu. Je dôležité preto pripomenút, že jeho aktuálny stav je „zrkadlom“ životného štýlu jedinca.

Ciel’om štúdie bolo posúdit stav telesného zloženia a antropometrických parametrov u detí mladšieho školského veku.

\section{METODIKA}

\section{Výskumný súbor}

Sledovaný súbor tvorili deti mladšieho školského veku, chlapci (n-117) a dievčatá (n-105) navštevujúci základné školy v Prahe vo vekovom rozmedzí 8-11 rokov (priemerný vek chlapci $=9,0 \pm 1,0$ rokov, telesná výška $=139,9 \pm 8,6 \mathrm{~cm}$, telesná hmotnost' $\left.=32 \pm 7,5 \mathrm{~kg}, \mathrm{BMI}=16,3 \pm 2,4 \mathrm{~kg} \cdot \mathrm{m}^{-2}\right)$. Priemerný vek dievčatá $=8,9 \pm 0,9$ rokov, telesná výška $=137,3 \pm 8,8 \mathrm{~cm}$, telesná hmotnost̉ $=$ $30,5 \pm 7,3 \mathrm{~kg}$, BMI $\left.=15,9 \pm 2,4 \mathrm{~kg} \cdot \mathrm{m}^{2}\right)$. Výber súboru prebiehal náhodne podl'a dostupnosti a záujmu oslovených základných škôl.

Kritériom zaradenia do štúdie bola neúčast detí v športových triedach a vek probandov 8-11 rokov. Testovanie prebehlo so súhlasom Etickej komisie FTVS UK, riaditel’ov základných škôl a rodičov testovaných detí, ktorí boli oboznámení s cielom a priebehom celého testovania a podpísali informovaný súhlas. Meranie prebehlo jednorázovo v priestoroch vybraných základných škôl v Prahe.

\section{Použité metódy}

Zo základných antropometrických parametrov boli meraná telesná výška $(\mathrm{cm})$ a telesná hmotnost’ $(\mathrm{kg})$. Telesná výška $(\mathrm{cm})$ bola stanovená pomocou antropometru s presnostou na $0,1 \mathrm{~cm}$. Telesná hmotnost $(\mathrm{kg})$ bola meraná pomocou digitálnej váhy s presnostou na $0,1 \mathrm{~kg}$. Bol stanovený index BMI $\left(\mathrm{kg} . \mathrm{m}^{-2}\right)$ hodnotený podl'a noriem pre deti od WHO (2016) a určenie percentilu v porovnaní s porovnávacími dátami českej populácie (Vignerová, Bláha, 2001).

K analýze telesného zloženia bol použitý multifrekvenčný prístroj BIA $2000 \mathrm{M}$, ktorý umožňuje celotelovú analýzu telesného zloženia.

Časová doba merania pri bioimpedancii nehrá rolu v prípade, že sú pre meranie zaistené potrebné podmienky a to hlavne príjem tekutín. U nami sledovaných probandov bol ich príjem tekutín kontrolovaný 2 hodiny pred samotným meraním a na otázku stavu ich pitného režimu odpovedali probandi deň pred vykovaním samotného merania.

Sledované boli predovšetkým nasledujúce parametre: telesný tuk (FM), celková telesná voda (TBW), koeficient ECM/BCM. Koeficient ECM/BCM je možné využit k posúdeniu morfologických predpokladov pre pohybovú aktivitu a aktuálny stav pohybového aparátu jedinca (Bunc, 2007, Heyward a Wagner, 2004).

Telesné zloženie bolo vyhodnotené pomocou softwaru NUTRI4 s použitím predikčných rovníc pre českú detskú populáciu podl’a Bunca et al. (2000).

\section{Štatistické spracovanie}

K analýze dát a ich štatistickému spracovaniu sme použili programy SPSS a Microsoft Excel. Pre popis súboru boli využité základné štatistické charakteristiky (aritmetický priemer, smerodajná odchýlka, min a max hodnoty). K určeniu vecnej významnosti u príslušných parametrov sme si stanovili rozdiel hodnôt hmotnosti väčší ako $1 \mathrm{~kg}$, rozdiel podielu telesného tuku väčší ako 1,5\%, rozdiel u ECM/BCM väčší o 0,05 a rozdiel u podielu celkovej telesnej vody (TBW) sme určili, že musí byt väčší ako $1 \%$. Hladina významnosti bola zvolená $\mathrm{p}<0,05$.

Konkrétne hodnoty vecnej významnosti boli stanovené na základe štúdie Česáka a kol. (2014). 


\section{VÝSLEDKY}

Priemerné hodnoty základných antropometrických charakteristík u chlapcov (Tab. 1) u dievčat (Tab. 2) a jednotlivých parametrov z analýzy telesného zloženia BIA 2000 M, u chlapcov (Tab. 3) u dievčat (Tab. 4) sú uvedené tabul'kovo.

Tab. 1: Základné antropometrické charakteristiky detí mladšieho školského veku - chlapci $(n=117)$ (hodnoty sú uvedené v tvare aritmetický priemer \pm smerodajná odchýlka, min-max hodnota)

\begin{tabular}{|l|c|c|}
\hline chlapci & priemer \pm SD & min-max \\
\hline Vek $($ roky) & $9,0 \pm 1,0$ & $8-11$ \\
\hline Telesná hmotnost $(\mathrm{kg})$ & $32,0 \pm 7,5$ & $20-70$ \\
\hline Telesná výška $(\mathrm{cm})$ & $139,9 \pm 8,6$ & $122-170,5$ \\
\hline BMI $\left(\mathrm{kg} \cdot \mathrm{m}^{-2}\right)$ & $16,3 \pm 2,4$ & $11,6-28,4$ \\
\hline
\end{tabular}

Priemerná hodnota BMI $\left(\mathrm{kg} \cdot \mathrm{m}^{-2}\right)$ sledovaného súboru chlapcov 16,3 $\pm 2,4 \mathrm{~kg} \cdot \mathrm{m}^{-2}$ zodpovedá odporúčanému rozmedziu pre optimálnu telesnú hmotnost̉ pre deti mladšieho školského veku (BMI = 15,5-21,9 kg.m $\left.{ }^{-2} \mathrm{WHO}, 2016\right)$. Pri individuálnom hodnotení jednotlivých probandov spadalo 69 chlapcov $(58,9 \%)$ do normálneho rozmedzia pre hodnotenie telesnej hmotnosti $(\mathrm{BMI}=$ $\left.15,5-21,9 \mathrm{~kg} \cdot \mathrm{m}^{-2}\right), 1$ proband $(0,008 \%)$ sa radil do kategórie nadváhy $\left(\mathrm{BMI}=22,0-26,9 \mathrm{~kg} \cdot \mathrm{m}^{-2}\right)$ a 1 proband $(0,008 \%)$ do kategórie obezity $\left(\mathrm{BMI}=27,0\right.$ a viac $\left.\mathrm{kg} \cdot \mathrm{m}^{-2}\right)$.

V porovnaní s porovnávacími dátami českej populácie (Vignerová, Bláha, 2011) sa hodnoty BMI u nami sledovaných chlapcov pohybovali na priemernej úrovni.

Tab. 2: Základné antropometrické charakteristiky detí mladšieho školského veku - dievčatá $(n=105)$ (hodnoty sú uvedené $v$ tvare aritmetický priemer \pm smerodajná odchýlka, min-max hodnota)

\begin{tabular}{|l|c|c|}
\hline dievčatá & priemer \pm SD & min-max \\
\hline Vek $($ roky) & $8,9 \pm 0,9$ & $8-11$ \\
\hline Telesná hmotnosṫ $(\mathrm{kg})$ & $30,5 \pm 7,3$ & $19-56$ \\
\hline Telesná výška $(\mathrm{cm})$ & $137,3 \pm 8,8$ & $117-161,8$ \\
\hline BMI $\left(\mathrm{kg} . \mathrm{m}^{-2}\right)$ & $15,9 \pm 2,4$ & $11,6-25,4$ \\
\hline
\end{tabular}

Priemerná hodnota BMI $\left(\mathrm{kg} . \mathrm{m}^{-2}\right)$ sledovaného súboru dievčat $15,9 \pm 2,4 \mathrm{~kg} \cdot \mathrm{m}^{-2}$ zodpovedá odporúčanému rozmedziu pre optimálnu telesnú hmotnost pre deti mladšieho školského veku (BMI = 15,5-21,9 kg.m ${ }^{-2}$ WHO, 2016).

Pri individuálnom hodnotení jednotlivých probandov spadalo 49 dievčat $(46,6 \%)$ do normálneho rozmedzia pre hodnotenie telesnej hmotnosti $\left(\mathrm{BMI}=15,5-21,9 \mathrm{~kg} \cdot \mathrm{m}^{-2}\right)$ a 3 probandi $(0,02 \%)$ sa radili do kategórie nadváhy $\left(\mathrm{BMI}=22,0-26,9 \mathrm{~kg} \cdot \mathrm{m}^{-2}\right)$.

V porovnaní s porovnávacími dátami českej populácie (Vignerová, Bláha, 2011) sa hodnoty BMI u dievčat pohybovali na priemernej úrovni.

Medzi chlapcami a dievčatami sme našli významné rozdiely v hodnotách priemernej hmot$\operatorname{nosti}(1,5 \mathrm{~kg})$. 
Tab. 3: Priemerné hodnoty jednotlivých parametrov z analýzy telesného zloženia BIA $2000 \mathrm{M}$ detí mladšieho školského veku - chlapci $(n=117)$ (hodnoty sú uvedené v tvare aritmetický priemer \pm smerodajná odchýlka, min-max hodnota)

\begin{tabular}{|l|c|c|}
\hline chlapci & priemer \pm SD & min-max \\
\hline FM $(\%)$ & $16,1 \pm 2,4$ & $11,5-31,4$ \\
\hline Koeficient ECM/BCM & $1,0 \pm 0,13$ & $0,64-1,72$ \\
\hline TBW $(\%)$ & $65,5 \pm 6,0$ & $45,7-87,0$ \\
\hline
\end{tabular}

Legenda: FM - tuková hmota (\%), koeficient ECM/BCM, TBW - celková telesná voda (\%)

Zistená priemerná hodnota telesného tuku (FM) u chlapcov mladšieho školského veku bola pomerne nízka 16,1 $\pm 2,4 \%$, čo zodpovedá odporúčanému rozmedziu pre optimálnu telesnú hmotnost u chlapcov mladšieho školského veku (FM = 14,1-23,0\% WHO, 2016). Priemerná hodnota TBW u probandov bola $65,5 \pm 6,0 \%$, čo signalizuje vyšší podiel beztukovej hmoty (FFM).

Rozmedzie hodnôt TBW sa pohybovalo 45,7-87,0\%. Uvedené hodnoty podporujú tvrdenie Riegrovej a kol. (2010), ktorá uvádza, že TBW predstavuje optimálne $60 \%$ telesnej hmotnosti.

Priemerná hodnota koeficientu ECM/BCM (parameter pre hodnotenie stavu výživy jedinca) u sledovaného súboru chlapcov bol 1,0 $\pm 0,13$.

Tab. 4: Priemerné hodnoty jednotlivých parametrov z analýzy telesného zloženia BIA $2000 \mathrm{M}$ detí mladšieho školského veku - dievčatá $(n=105)$ (hodnoty sú uvedené v tvare aritmetický priemer \pm smerodajná odchýlka, min-max hodnota)

\begin{tabular}{|l|c|c|}
\hline dievčatá & priemer \pm SD & min-max \\
\hline FM $(\%)$ & $16,5 \pm 2,9$ & $12,6-29,2$ \\
\hline Koeficient ECM/BCM & $1,02 \pm 0,11$ & $0,74-1,37$ \\
\hline TBW $(\%)$ & $66,6 \pm 6,5$ & $46,2-80,0$ \\
\hline
\end{tabular}

Legenda: FM - tuková hmota (\%), koeficient ECM/BCM, TBW - celková telesná voda (\%)

Zistená priemerná hodnota telesného tuku (FM) u dievčat bola vzhl'adom na odporúčané hodnoty pre optimálnu telesnú hmotnost’ u dievčat mladšieho školského veku podl'a WHO (2016) vel'mi nízka $(16,5 \pm 2,9 \%)$. Výsledky zodpovedajú rozmedziu podváhy u dievčat mladšieho školského veku $(<17,0)$. Odporúčané rozmedzie pre optimálnu telesnú hmotnost̉ u dievčat mladšieho školského veku predstavuje FM = 17,1-26,0\% (WHO, 2016).

Priemerná hodnota TBW u probandiek bola $66,6 \pm 6,5 \%$. Rozmedzie hodnôt TBW sa pohybovalo 46,2-80,0\%. Oproti chlapcom $(65,5 \pm 6,0 \%)$ z nami sledovaného súboru, tak dievčatá dosiahli vyšších hodnôt TBW o 1,1 \%. Tieto výsledky poukázali na nezvyklý fakt, nakol'ko normy hodnôt TBW pre mladší školský vek, ktoré stanovil Bunc (2007b), výsledky, ktoré publikoval Bunc (2008) a Česák a kol. (2014) poukazujú na spravidla nižšie hodnoty TBW u dievčat oproti chlapcom. Priemerná hodnota TBW u dospelých žien sa pohybuje medzi 50-60\% a u dospelých mužov je to 55-65\% v prípade normálnej hmotnosti.

Priemerná hodnota koeficientu ECM/BCM u sledovaného súboru dievčat bola 1,02 $\pm 0,11$.

Medzi chlapcami a dievčatami sme nenašli vecne významné rozdiely v podiely telesného tuku $(0,4 \%)$ a ani v koeficiente ECM/BCM $(0,02)$. Vecne významné rozdiely u skúmaného súboru sme však našli v hodnotách priemerného podielu celkovej telesnej vody (TBW) a to 1,1\%. 


\section{DISKUSIA}

Sledovanie antropometrických parametrov a analýza telesného zloženia, resp. zastúpenie a vztah jednotlivých komponentov telesného zloženia, môžu byt vhodným ukazovatel'om nielen nutričného stavu jedinca, ale taktiež ukazovatel’om vplyvu pohybovej aktivity na organizmus (Kinkorová, 2015).

Ukazovatel' pohybovej aktivity je jeden z využitel'ných parametrov, ktorý je potrebné vyhodnocovat $\mathrm{v}$ kontexte s genetických dispozíciami, stravovacími návykmi, či so sociálnym a ekonomickým prostredím $\mathrm{v}$ ktorom jedinec žije a vyrastá.

V nameraných hodnotách telesnej výšky $(\mathrm{cm})$ a telesnej hmotnosti $(\mathrm{kg}) \mathrm{u}$ jednotlivých probandov sledovaného súboru (chlapci a dievčatá mladšieho školského veku) boli viditel'né významné rozdiely. Priemerná telesná výška chlapcov bola 139,9 8,6 cm (rozmedzie 122-170,5 cm, rozdiel $48,5 \mathrm{~cm}$ ), priemerná telesná hmotnost' bola $32 \pm 7,5 \mathrm{~kg}$ (rozmedzie $20-70 \mathrm{~kg}$, rozdiel $50 \mathrm{~kg}$ ).

Dôvodom týchto významných rozdielov boli pravdepodobne genetické faktory, odlišný somatotyp, rozdielny nutričný a pohybový režim sledovaných detí.

Hodnoty priemernej telesnej výšky $(\mathrm{cm})$ a priemernej telesnej hmotnosti $(\mathrm{kg}) \mathrm{v}$ podstate odpovedajú hodnotám podla Bunca (2008), ktorý vo svojej štúdii uvádza priemernú telesnú výšku u detí mladšieho školského veku, chlapci 143,4 $\pm 4,1(\mathrm{~cm})$ a priemernú telesnú hmotnost’ $34,2 \pm 3,2(\mathrm{~kg})$. Dievčatá, priemerná telesná výška 145,2 $\pm 4,6(\mathrm{~cm})$ a $35,0 \pm 4,6$ priemerná telesnú hmotnost' $(\mathrm{kg})$. Z hl'adiska normatívnych hodnôt BMI pre mladší školský vek podla WHO (2016) spadalo 69 chlapcov $(58,9 \%)$ do normálneho rozmedzia pre hodnotenie telesnej hmotnosti $\left(\mathrm{BMI}=15,5-21,9 \mathrm{~kg} \cdot \mathrm{m}^{-2}\right), 1$ proband sa radil do kategórie nadváhy $\left(\mathrm{BMI}=22,0-26,9 \mathrm{~kg} \cdot \mathrm{m}^{-2}\right)$ a 1 proband do kategórie obezity $\left(\mathrm{BMI}=27,0\right.$ a viac $\left.\mathrm{kg} \cdot \mathrm{m}^{-2}\right)$.

V porovnaní s porovnávacími dátami českej populácie (Vignerová, Bláha, 2011) sa hodnoty telesnej výšky u nami sledovaných chlapcov pohybovali na nadpriemernej úrovni, hodnoty telesnej hmotnosti a hodnoty BMI indexu patrili k priemeru (50. percentil). Hodnoty telesnej výšky, telesnej hmotnosti i hodnoty BMI sa u dievčat pohybovali na priemernej úrovni (50. percentilu). Výsledky ukázali, že hodnoty vybraných parametrov u nami sledovaného súboru dievčat a chlapcov patrili k priemernej úrovni (s výnimkou telesnej výšku chlapcov 75. percentil).

Měkota, Kovář (1996) uvádzajú, že telesná výška a hmotnost̉ jedinca sú nepriamymi ukazovatel'mi zdatnosti a výkonnosti. Ide o ukazovatele, ktoré poukazujú na úroveň telesného rozvoja a zloženia tela detí.

Z pohl'adu antropometrických ukazovatel’ov a v porovnaní s dátami českej populácie (Vignerová, Bláha, 2011) by sme mohli nami sledovaný súbor na základe získaných výsledkov zaradit $\mathrm{k}$ detom s priemernou úrovňou telesnej zdatnosti. U dievčat do normálneho rozmedzia pre hodnotenie telesnej hmotnosti $(\mathrm{BMI}=15,5-21,9)$ spadalo 49 dievčat $(46,6 \%)$ a 3 dievčatá $(0,02 \%)$ sa radili do kategórie nadváhy $\left(\mathrm{BMI}=22,0-26,9 \mathrm{~kg} \cdot \mathrm{m}^{-2}\right)$.

Dôvodom zaradenia niektorých chlapcov i dievčat do kategórie nadváhy (podla BMI = 22,0-26,9 kg. $\mathrm{m}^{-2}$ ) bolo spôsobené vyšším zastúpením percenta tuku a nižším zastúpením celkovej telesnej vody (TBW). Všetci sledovaní probandi, ktorí boli podl'a výsledkov BMI zaradení do kategórie nadváhy, vykazovali rovnako tak hodnoty percenta telesného tuku, ktoré ich zarad’ujú do kategórie nadváhy podla WHO (2016). Chlapci $(\mathrm{FM}=23,1-28,0 \%)$ a dievčatá $(\mathrm{FM}=$ 26,1-31,0\%).

Zásadným je hmotnostný stav rodičov. Priama genetická predurčenost̉ nadváhy alebo obezity je cca 49,5\% (Bouchard, 2010). Príkladná "genetická” podmienenost je následne až 75\% (Bunc, 2008). Podobným porovnávaním antropometrických parametrov a parametrov telesného zloženia sa zaoberal napr. Bunc (2008) a Bunc (2014). Porovnávanie s výsledkami tejto štúdie je uvedené v Tab. 5. 
Tab. 5: Porovnanie jednotlivých parametrov detí mladšieho školského veku (chlapcov a dievčat) s d’alšími štúdiami (hodnoty sú uvedené v tvare aritmetický priemer \pm smerodajná odchýlka, min-max hodnota)

\begin{tabular}{|l|l|c|c|c|c|c|c|}
\hline Štúdia & Súbor & $\mathbf{n}$ & Vek (roky) & $\begin{array}{c}\text { Telesná výška } \\
\text { (cm) }\end{array}$ & $\begin{array}{c}\text { Telesná } \\
\text { hmotnost } \\
\text { (kg) }\end{array}$ & $\begin{array}{c}\text { Tuk (\%) } \\
\text { (metodika } \\
\text { BIA) }\end{array}$ & $\begin{array}{c}\text { ECM/BCM } \\
\text { koeficient }\end{array}$ \\
\hline \multirow{2}{*}{$\begin{array}{l}\text { Súčasná } \\
\text { śtúdia }\end{array}$} & $\begin{array}{l}\text { Chlapci MŠV } \\
\text { (Praha) }\end{array}$ & 117 & $9,0 \pm 1,0$ & $139,9 \pm 8,6$ & $32,0 \pm 7,5$ & $16,1 \pm 2,4$ & $1,0 \pm 0,13$ \\
\cline { 2 - 8 } & $\begin{array}{l}\text { Dievčatá MŠV } \\
\text { (Praha) }\end{array}$ & 105 & $8,9 \pm 0,9$ & $137,3 \pm 8,8$ & $30,5 \pm 7,3$ & $16,5 \pm 2,9$ & $1,02 \pm 0,11$ \\
\hline \multirow{2}{*}{$\begin{array}{l}\text { Bunc } \\
(2008)\end{array}$} & $\begin{array}{l}\text { Chlapci MŠV } \\
\text { (Česko) }\end{array}$ & 450 & $10,2 \pm 2,7$ & $143,4 \pm 4,1$ & $34,2 \pm 3,2$ & $19,7 \pm 5,3$ & $0,90 \pm 0,04$ \\
\cline { 2 - 8 } & $\begin{array}{l}\text { Dievčatá MŠV } \\
\text { (Česko) }\end{array}$ & 340 & $10,1 \pm 2,8$ & $145,2 \pm 4,6$ & $35,0 \pm 4,6$ & $21,7 \pm 5,0$ & $0,92 \pm 0,05$ \\
\hline \multirow{2}{*}{$\begin{array}{l}\text { Bunc } \\
(2014)\end{array}$} & $\begin{array}{l}\text { Chlapci MŠV } \\
\text { (Česko) }\end{array}$ & 1810 & $12,8 \pm 3,7$ & $157,1 \pm 4,6$ & $49,8 \pm 3,1$ & $20,3 \pm 1,5$ & $0,81 \pm 0,04$ \\
\cline { 2 - 8 } \\
$\begin{array}{l}\text { Dievčatá MŠV } \\
\text { (Česko) }\end{array}$ & 1598 & $12,5 \pm 3,5$ & $157,0 \pm 4,8$ & $48,0 \pm 3,6$ & $19,6 \pm 1,7$ & $0,91 \pm 0,03$ \\
\hline
\end{tabular}

Nami sledovaní probandi (chlapci a dievčatá mladšieho školského veku) dosahovali v porovnaní s výsledkami Bunca (2008) predovšetkým nižších hodnôt telesnej výšky (cm). V porovnaní s výsledkami Bunca (2014) dosahovali naše deti mladšieho školského veku aj nižšej telesnej hmotnosti ( $\mathrm{kg})$ aj nižších hodnôt telesného tuku (\%) a to u oboch pohlaví. U nami sledovaného súboru detí sme našli významné rozdiely $\mathrm{v}$ hodnotách priemernej hmotnosti $(1,5 \mathrm{~kg})$, ale nenašli významné rozdiely v podiely telesného tuku $(0,4 \%)$

Podl'a nášho názoru tieto rozdiely mohli byt spôsobené rozdielnou charakteristikou súboru. Nami sledovaný súbor tvoril deti, ktoré pochádzali z Prahy. Tieto deti tak tvorili špecifickú skupinu sledovaného súboru, nakol'ko sa životný štýl populácie vel'komesta od životného štýlu v malomeste či na dedine líši. Ide najmä o rozdielnost’ socioekonomickej situácie, kultúrnych a demografických charakteristík obyvatel'stva. Vel'komesto sa vyznačuje vysokou koncentráciou obyvatel'stva a l'udských aktivít na relatívne malej ploche (Matlovič, 2001).

Deti žijúce vo vel'komeste majú okrem iného väčšie možnosti výberu a praktizovania pohybových aktivít oproti ich rovesníkom žijúcim v menších mestách. Vel'komesto ponúka väčšie možnosti zapojenia detí do pravidelných pohybových aktivít či už prostredníctvom školských krúžkov alebo športových klubov. Deti tak majú na výber širšiu paletu pohybových aktivit, ktoré by ich mohli bavit a nie sú tak limitované obmedzeným výberom, ako deti žijúce v malomeste alebo na dedine. Práve tieto deti boli súčastou štúdie Bunca (2008 a 2014), ktoré pochádzali z územia celej Českej republiky. Súčastou obidvoch štúdií, tak boli jedinci rozdielneho veku, stupňa telesného vývoja i prostredia v ktorom jedinci žili. Telesné zloženie sa podl’a Pařízkovej (1998) mení v závislosti na veku, pohlaví, stupni telesného vývoja a pohybovej činnosti. Česák a kol. (2014) uvádzajú, že telesné zloženie je ovplyvnené kvalitou života, ktorá je daná prostredím, v ktorom jedinec vyrastá a žije.

Pri porovnávaní výsledkov z týchto štúdií sme vynechali ukazovatel' BMI indexu nakol'ko rovnako, ako WHR index (pomer pás/boky) nepodáva podrobné informácie o zastúpení jednotlivých komponentov telesného zloženia. Preto sa pri meraní telesného zloženia odporúča použit niektorú $\mathrm{z}$ bežne dostupných prístrojových metodík, napr. BIA. Čo sa týka výsledkov analýzy telesného zloženia, je dôležité zdôraznit, že každý z jednotlivých komponentov telesného zloženia má svoj význam a pri hodnotení nameraných hodnôt je potrebné prihliadat $\mathrm{k}$ individuálnej variabilite každého jedinca. 
Celková telesná voda (TBW), ktorá patrí medzi jeden z najvýznamnejších komponentov zloženia tela, ovplyvňuje predovšetkým denzitu beztukovej hmoty, ale taktiež aj odhad telesného tuku (\%) (Kinkorová, Vrba 2015). Taktiež je to otázka termoregulácie a viskozity krvi. Hodnoty celkovej telesnej vody (TBW) sú závislé hlavne na metóde merania. Metóda bioimpedancie, ktorá bola v našej štúdii použitá meria primárne vodu preto je u tejto metódy dôležité zaistenie konštantnej hydratácie organizmu.

Česák a kol. (2014) ktorí zistovali stav telesného zloženia u detí mladšieho školského veku v okrese Most a v Prahe, uvádzajú podiel celkovej telesnej vody (\% TBW) u chlapcov z okresu Most 59,5 $\pm 2,5 \%$ a u dievčat 59,6 $\pm 4,0 \%$. U detí z Prahy dosiahli chlapci hodnôt $65,6 \pm 2,5 \%$ a dievčatá $59,0 \pm 2,9 \%$. Bunc (2007b) stanovil normy podielu celkovej telesnej vody u chlapcov vo veku 11 rokov na hodnoty $64,3 \pm 3,1 \%$ a u dievčat v rovnakom veku $61,5 \pm 3,6 \%$. Podl'a Gáby a kol. (2011) je celková telesná voda východiskovou premennou pre stanovenie telesného zloženia prostredníctvom metódy bioelektrickej impedancie. Ovplyvňuje teda aj d’alšie telesné frakcie (napr. množstvo telesného tuku).

Podl’a Bunca (2009) je adekvátny stav hydratácie organizmu podmienkou pre stanovenie telesného zloženia, kedy stav hydratácie môže spôsobit chybu vo výsledkoch o vel'kosti $2-4 \%$. Metodika BIA neumožňuje rozlíšenie podkožného a štrukturálneho tuku, je možné zistit iba celkové zastúpenie telesného tuku (\%) v organizme. Literatúra dokladá, že existujú rozdiely medzi pohlaviami v množstve a distribúcii telesného tuku. Tieto rozdiely sú dané predovšetkým hormonálne, muži ukladajú viac tuku do brušnej oblasti, ženy zasa do oblasti stehien a panvy. Ženské telo spravidla obsahuje väčšie množstvo tukového tkaniva, menšie množstvo svalov a má i inú distribúciu telesného tuku, ako mužské telo. Na množstve a distribúcii telesného tuku sa taktiež v nemalej miere podiel'a aj odlišná úroveň pohybovej aktivity (Herland, Haarbo \& Christiansen, 1998).

Množstvo telesného tuku bolo u sledovaných jedincov v priemere chlapci $16,1 \pm 2,4 \%$ a dievčatá $16,5 \pm 2,9 \%$, čo v kontexte s antropometrickými výsledkami a d’alšími parametrami telesného zloženia, napr. množstvom TBW, môžeme považovat za pomerne nízke hodnoty. Najvyššou zistenou hodnotou telesného tuku u chlapcov bolo $28,4 \%$ a u dievčat $25,42 \%$. Výsledky štúdie Česák a kol. (2014) ukázali, že socioekonomická úroveň prostredia má dopad na životný štýl, ktorý má značný efekt na telesné zloženie.

Podl’a nášho názoru sú dôvodom nízkych hodnôt telesného tuku u nami sledovaných detí dva hlavné dôvody. Prvým je fakt, že deti v sledovanom súbore pochádzali z Prahy. Česák a kol. (2014) uvádzajú, že rozdiely medzi pražským regiónom a ostatnými regiónmi v Českej republike sa nachádzajú najmä v percente nezamestnanosti, v priemernom platovom ohodnotení, v priemernom počte trestných činov na 1000 obyvatel'ov, ale taktiež aj v zdravotnej starostlivosti, respektíve v priemernom počte lekárov na 1000 obyvatel’ov. To všetko má dopad na životný štýl, ktorý má značný efekt na telesné zloženie. Bunc (2014) uvádza, že ekonomická situácia rodiny determinuje pravidelnú realizáciu pohybovej aktivity, jej formu a kvalitu. Pražské deti tak majú oproti svojim rovesníkom z ostatných regiónov Českej republiky nielen vy̌šsiu ekonomickú výhodu, ale rovnako tak aj výhodu nižšej chorobnosti a predovšetkým väčšiu výhodu v širších možnostiach výberu vhodných pohybových aktivít. A práve pohybová činnost̉ spolu s výživou a chorobnostou podla Kutača (2009) a Bunca (2000) spolu s genetikou ovplyvňuje stav telesného zloženia.

Druhým dôvodom je fakt, že naša štúdia pozostávala z detí priemerného veku 9,0 $\pm 1,0$ (chlapci) a 8,9 $\pm 0,9$ (dievčatá). Bunc (2004) uvádza, že deti veku 7-8 rokov majú v priemere vrátane školskej telesnej výchovy 7,5 hodín pohybových aktivít týždenne. Vo veku 14 rokov majú v priemere už iba 2,1 hodín pohybu týždenne. U tohto súboru detí vo veku do dvanást rokov sa objavuje cca 10-12\% detí s nadváhou (zhruba rovnaké percento u chlapcov a dievčat). Od tohto veku sa u dievčat percento jedincov s nadváhou zvyšuje a dosahuje cca $16-20 \%$ vo veku 18 rokov. U chlapcov nie je nárast nadváhy v rovnakom vekovom období tak výrazný, štúdia poukazuje na cca 
14\% detí s nadváhou (Bunc, 2004). Nami sledovaný súbor detí (priemerný vek 9,0 $\pm 1,0$ chlapci a 8,9 $\pm 0,9$ dievčatá) tak patrí z hl'adiska veku k pohybovo najviac aktívnym detom. Śtúdie ukazujú, že hodnoty telesného tuku a riziko nadváhy alebo obezity sa zvyšujú vekom. Černá (2011) vo svojej práci uvádza nárast hodnôt telesného tuku u detí mladšieho školského veku, chlapci 8-10 rokov (nárast o 1,4\%) a dievčatá 9-11 rokov (nárast o 2,2\%) oproti nami sledovanému súboru 222 detí, kde sa podla WHO (2016) 4 jedinci $(0,018 \%)$ radili do kategórie nadváhy a $1(0,004 \%)$ do kategórie obezity. Všetci jedinci sa nachádzali vo veku 10-11 rokov, čo potvrdzuje zistenia d’alších autorov. WHO (2016) zarad’uje chlapcov vo veku 6-14 s množstvom telesného tuku nad 28,1 \% do kategórie obezity a dievčatá vo veku 6-14 rokov s množstvom telesného tuku v rozmedzí 23,1-28,0\% do kategórie nadváhy.

Podl’a Kutáča (2012) je porovnávanie jednotlivých štúdií iba orientačné a často problematické, pretože autori množstva vedeckých publikácií sa líšia v hornej hranici hodnôt, ktoré ešte považujú za normové a pomerne často nie je v štúdiách uvedený spôsob realizácie merania (napr. použité prístroje, výskumný súbor atd’.). Podl’a Gáby a kol. (2011) je z hl'adiska posudzovania zdravotného rizika vzhl'adom k telesnému tuku dôležité merat nielen celkové zastúpenie, ale aj posúdit množstvo $\mathrm{v}$ jednotlivých segmentoch. Vel'kost koeficientu ECM/BCM bol u sledovaných jedincov $\mathrm{v}$ priemere u chlapcov $1,0 \pm 0,13$ a u dievčat $1,02 \pm 0,11$.

Zvlášt dôležitá je extracelulárna hmota (ECM) a intracelulárna hmota (BCM) (Bunc, 2007b, Heyward a Wagner, 2004). Pretože oba tieto parametre sú závislé na telesnej hmotnosti, využívame pre hodnotenie pomer ECM/BCM. Jeho hodnota je závislá na veku a realizovanom pohybovom zatažení. Podstatné je, že vo vekovom období 20 až 60 rokov zostáva tento pomer u jedincov s rovnakým pohybovým režimom praktický nezávislý na veku (Bunc, 2007b). Podstatné je množstvo hmoty mimo bunku (ECM) a vo vnútri bunky (BCM). Ich súčet tvorí beztukovú hmotu (FFM). Pretože FFM je vo vztahu s celkovou hmotnostiou jedinca, je výhodné pre porovnanie osôb s rôznou hmotnostou, využívat pomer ECM/BCM. Všeobecne platí, že čím je táto hodnota nižšia, tým väčšie je množstvo BCM a tým lepšie sú predpoklady pre svalovú prácu (Bunc et al. 2000). Lepšie predpoklady pre svalovú prácu, väčšie množstvo BCM a hlavne následné nižšie hodnoty koeficientu ECM/BCM, sú potvrdené i významne vyššou motorickou výkonnostou aktívnych detí (Bunc, 2008), ako ukazuje Tabul'ka 6.

Tab. 6: Priemerné hodnoty vybraných antropometrických a maximálnych funkčných parametrov u detí mladšieho školského veku (chlapcov a dievčat). Bunc (2008)

\begin{tabular}{|l|c|c|c|c|}
\hline & Chlapci neakt. & Chlapci akt. & Dievčatá neakt. & Dievčatá akt. \\
\hline Vek (roky) & $10,2 \pm 2,7$ & $10,4 \pm 2,6$ & $10,1 \pm 2.8$ & $10,3 \pm 2,9$ \\
\hline $\mathrm{BCM}(\mathrm{kg})$ & $14,7 \pm 3,4$ & $17,1 \pm 3,6$ & $14,6 \pm 3,6$ & $16,3 \pm 3,2$ \\
\hline Koeficient ECM/BCM & $0,90 \pm 0,04$ & $0,81 \pm 0,06$ & $0,92 \pm 0,05$ & $0,86 \pm 0,04$ \\
\hline $\mathrm{VO}_{2 \max } \cdot \mathrm{kg}^{-1}\left(\mathrm{ml} \cdot \mathrm{kg}^{-1} \cdot \mathrm{min}^{-1}\right)$ & $44,9 \pm 5,6$ & $51,8 \pm 6,2$ & $40,3 \pm 5,2$ & $45,9 \pm 5,6$ \\
\hline $\mathrm{V}_{\max }\left(\mathrm{km} \cdot \mathrm{h}^{-1}\right) 5 \%$ & $13,1 \pm 2,3$ & $14,3 \pm 2,0$ & $9,8 \pm 2,1$ & $12,1 \pm 2,4$ \\
\hline
\end{tabular}

Celková doba trvania pohybového zataženia za týždeň sa u neaktívnych detí pohybovala v rozmedzí od 120 do 250 minút. U aktívnych detí to bolo v rozmedzí 480-1200 minút. Priemerná energetická náročnost’ sa u neaktívnych detí pohybovala v rozmedzí $1360 \mathrm{kcal}(5685 \mathrm{~kJ})$ až $2620 \mathrm{kcal}(10952 \mathrm{~kJ})$, (priemer $1980 \pm 310 \mathrm{kcal}-8276 \pm 1296 \mathrm{~kJ}$ ). U aktívnych detí sa celková energetická náročnost’ pohybovala v pásme $7400 \mathrm{kcal}(30930 \mathrm{~kJ})$ až $12600 \mathrm{kcal}(52670 \mathrm{~kJ})$ (priemer $9800 \pm 520 \mathrm{kcal}-40960 \pm 2174 \mathrm{~kJ}$ ) za týždeň (Bunc, 2008). 
Parametre charakterizujúce telesné zloženie a to hlavne hodnoty BCM a podiel ECM/BCM jednoznačne odrážajú absolvovaný pohybový režim a sú významne lepšie u aktívnych detí s pravidelným pohybovým režimom.

V praxi to znamená, že tieto deti majú významne lepšie predpoklady pre svalovú prácu ako deti neaktívne. Na druhej strane to rovnako potvrdzuje predpoklad, že parametre telesného zloženia sú schopné reflektovat pohybový režim a teda taktiež aj aktívny životný štýl (Bunc, 2008). Ďalšou oblastou, ktorá má spojitost’ s vykonávaním pohybovej aktivity u detí je vplyv správania rodičov na pohybovú aktivitu detí a mládeže.

Autori zahraničnej odbornej literatúry sa vo vel'kej miere zhodujú na tom, že pozitívna podpora rodičov predpokladá vyššiu pohybovú aktivitu (napr. Gustafson a Rhodes, 2006; Salis et al., 2002, Voss et al., 2008). Podl'a Vosse et al. (2008) má na túto problematiku svoj vplyv taktiež aj socioekonomická situácia rodiny a taktiež výška dosiahnutého vzdelania rodičov (Salis a Owen, 1999). Podl’a týchto štúdií sa znížená pohybová aktivita vyjadrená početnostou za týždeň objavuje u detí $\mathrm{z}$ rodín s nižšími finančnými príjmami a vyššia úroveň vzdelania rodičov významne pozitívne ovplyvňuje množstvo a početnost pohybovej aktivity ich detí.

V českom prostredí sa touto témou zaoberal napríklad Sigmund et al. (2008), ktorý skúmal vztah medzi pohybovou aktivitou rodičov a ich 8-13 ročných detí. Súbor tvorilo 193 detí (84 dievčat, 109 chlapcov z Olomouca) a ich rodičov (183 matiek a 157 otcov). Výsledky ukázali, Že pohybovo aktívnejší rodičia vychovávajú pohybovo aktívnejšie deti a naopak menej pohybovo aktívne matky a otcovia vychovávajú menej pohybovo aktívne dcéry a synov. Aj napriek tomu, že hlavným a podstatným faktorom, ktorý vedie k vzniku obezity alebo nadváhy je životný štýl alebo miera životného štýlu a z neho vyplývajúca energetická bilancia významným determinantom sú taktiež genetické dispozície. Podl'a niektorých literárnych prameňov sa jedná až o 50\% vplyv. (Heymsfield et al., 2005; Lisá et al., 2008). Množstvo štúdií (napr. Kemper et al., 1990; Malina a Bouchard, 2004, Mustelin et al., 2009) preukázalo, že nadváha a obezita v detstve a v období adolescencie prechádza pravidelne $\mathrm{v}$ obezitu dospelého veku.

Je preto vel'mi dôležité poznat aktuálny stav telesného zloženia a taktiež životný štýl mladej populácie a na základe tejto reflexie uskutočňovat preventívne opatrenia.

\section{ZÁVERY}

Zistené výsledky antropometrických parametrov u chlapcov, ich nízke zastúpenie telesného tuku $(16,1 \pm 2,4 \%)$ spolu s vyššími hodnotami koeficientu ECM/BCM $(1,0 \pm 0,13)$ a výsledky u dievčat telesný tuk $(16,5 \pm 2,9 \%)$ spolu s vyššími hodnotami koeficientu ECM/BCM $(1,02 \pm 0,11)$ poukazujú na vel'mi dobré predpoklady $\mathrm{k}$ všeobecnej telesnej výkonnosti a fyzickej zdatnosti sledovaných jedincov. Je však dôležité zdôraznit, že vzájomné vztahy jednotlivých telesných parametrov sú výrazne ovplyvnené individuálnou variabilitou daného jedinca. Môžeme sa jednoznačne priklonit k názorom, že nielen jednorázové, ale aj opakované meranie telesných parametrov je významnou informáciou úrovni zdatnosti, zdravotného stavu a o prípadnom pozitívnom či negatívnom vývoji každého jedinca či už detskej alebo dospelej populácie.

\section{Literatúra}

Andreoli, A., Melchiorri, G., Brozzi, M., Di Marco, A., Volpe, S. L., Garofano, P., Di Danikele, N. \& De Lorenzo, A. (2003). Effect of different sports on body cell mass in highly trained athletes. Acta diabetol., 40, 122-125.

Bouchard, C. (2010). Physical activity and obesity. Champaign: Human Kinetics.

Brettschneider, W. D., \& Naul, R. (2007). Obesity in Europe: Young People's Physical Activity and Sedentary Lifestyles: Lang.

Bunc, V. (2007a). Aktivní životní styl v biosociálním kontextu. Česká kinantropologie, 11 (3), 5-6. 
Bunc V. (2008). Aktivní životní styl dětí a mláděže jako determinant jejich zdatnosti a tělesného složení. Studia Kinanthropologica, IX, 2008, (1), 19-23.

Bunc, V., Dlouhá, R., Moravcová, J., Novák, I., Hošková, Z., \& Čermáková, M. (2000). Estimation of body composition by multifrequency bioimpedance measurement in children. Vol. 904 (pp. 203-204).

Bunc, V. (2014). Hypokinéza - př́činy a následky. Studia Kinanthropologica, XV, 2014, (3), 141-145.

Bunc, V. (2007b). Možnosti stanovení tělesného složení u dětí bioimpedanční metodou. Čas Lék Čes, 146(5), 492-496.

Bunc, V. (2010). Obezita a nadváha dětí - důsledek jejich neadekvátního pohybového režimu. In: Mužík, V., Vlček, P. et al. Škola a zdraví pro 21. století. Brno: MU, s. 35.

Bunc, V. (2004). Role pohybových aktivit v životě dětí a mládeže. (Role of the movement activities in the children and youth life). Závěrečná zpráva VZ MSM 115100001, Praha: UK FTVS.

Bunc, V., \& Štilec, M. (2007). Tělesné složení jako indikátor aktivního životního stylu seniorek. Česká Kinatropologie, 11(3), s.17-23.

12.. Bunc, V. (2009). Tělesné složení u adolescentů jako indikátor aktivního životního stylu. Česká kinantropologie, 13(3), 11-17.

Černá, L. (2011). Vztah vybraných somatických a motorických ukazovatelů k posturální stabilitě u dètí mladšího školního věku. Disertační práce, Praha: UK FTVS.

Česák M., Holický J., Česák P., Bunc V. (2014). Porovnání tělesného složení u dětí z odlišných socioekonomických regionů. Studia Kinanthropologica, XV, 2014, (3), 153-160.

Dlouhá, R., Heller, J., Bunc, V., Giampietro, M., Gambarara, D., Andreoli, A. \& Caldarone, G. (1998). Srovnání rovnic Pařízkové pro zjištování tělesného tuku sportujících žen. Med. Sport. Boh. Slov., 7 (1), 7-12.

Gába, A, Přidalová, M., Válková, H., Walkley, J. \& Gábová, Z. (2011). Hodnocení tělesného složení u jedinců se středně těžkou mentální retardací. Česká antropologie, 61(1), 15-20.

Gustafson, S.L. a Rhodes, R.E. Parental Correlates of Physical Activity in Children and Early Adolescents. Sports Medicine, 2006, 36(1), 79-97.

Heymsfield, S.B. et al. Human body composition. Champaign: Human Kinetics, 2005.

Herland, M. L., Haarbo, J. \& Christiansen, C. (1998) Regional body composition determined by dual energy x-ray absorptiometry. Relation to trainung, sex hormones, and serum lipids in male long-distance runners. Scand J Med Sci Sports, 8, 102-108.

Heyward, V. H., \& Wagner, D. R. (2004). Applied body composition assessment. Champaign: Human Kinetics.

Kemper, H.C. et al. Tracking of health and risk indicators of cardiovascular diseases from teenager to adult: Amsterdam Growth and Health Study. Prev. Med., 1990, 19, 642-655.

Kinkorová l., Vrba M. (2015). Stav antropometrických parametrů a tělesného složení u studentů Vojenského oboru UK FTVS v Praze. Studia Sportiva 2015 / č. 2, 57-67.

Konopka, Peter. (2004). Sportovní výživa. 1. vyd. České Budějovice: Kopp. 125 s.

Kutáč, P. (2009). Základy kinantropometrie: (pro studujicí obor Tv a sport): Pedagogická fakulta Ostravské univerzity v Ostravě, katedra tělesné výchovy.

Kutáč, P. (2012) Vývoj somatických parametrů hráčů ledního hokeje. Česká antropologie, 62, (2), 9-14.

Lisá, L. et al. Doporučený postup prevence a léčby dětské obezity. Praha: Čes.-slov. Pediat., 2008, roč. 63, č. 9, s. 501-507.

Malina, R. M., Bouchard, C., Bar-Or, O. (2004). Growth maturation and physical activity. 2. Vyd. Champaign: Human Kinetics.

Malina, R. M., Bouchard, C. (1991). Models and methods for studying body composition. Growth, maturation, and physical activity. Champaign: Human Kinetics, 1991.

Malá, L., Zahálka, F., Malý, T., \& Kollárová, B. (2009). Určenie telesného zloženia pomocou metódy hydrodenzitometrie. Paper presented at the Molisa 6 - Medicínsko-ošetrovatel'ské listy Šariša, Zborník, Prešov.

Matlovič, R. (2001). Transformačné procesy a ich efekty v intraurb. štruktúrach postkomunistických miest. Geografické štúdie 8, Banská Bystrica, 73-81.

Měkota, K., Novosad, J. (2005). Motorické schopnosti. Olomouc: UP.

Měkota, K., Kovář, R. et al. Unifittest 6-60. manuál pro hodnocení základní motorické výkonosti a vybraných charakteristik tělesné stavby mládeže a dospělých v České republice. Ostrava: Pedagogická fakulta Ostravské univerzity, 1996.

Mustelin, L. et al. Physical activity reduces the influence of genetic effects on BMI and waist circumference: a study in young adult twins. International Journal of Obesity, 2009, y. 33, pp. 29-36.

Pařízková, J. (1998). Složení těla, metody měření a využití ve výzkumu a lékařské praxi. Med. Sport Boh. Slov., 7, 1, s. 1-6.

Riegrová, J., Kapuš, O., Gába, A. \& Ščotka, D. (2010) Rozbor tělesného složení českých mužů ve věku 20 a 80 let (hodnocení tělesné výšky, hmotnosti, BMI, svalové a tukové frakce). Česká antropologie, 60 (1), 20-23.

Riegerová, M., Přidalová M., Ulbrichová, M. (2006). Aplikace fyzické antropologie v tělesné výchově a sportu: (příručka funkční antropologie). 3. vyd. Olomouc: Hanex.

Roche, A. F., Heymsfield, S.B., Lohman, T.G. (1996). Human body composition. Champaign: Human Kinetics.

Sallis, J. F. et al. Correlates of Vigorous Physical Activity for Children in Grades 1 Through 12: Comparing Parent-Reported and Objectively Measurement Physicasl Activity. Pediatric Exercise Science, 2002,14, pp. 30-44.

Sallis, J. F. a Owen, N. Physical Activity and Behavioral Medicine. Thousand Oaks, London: SAGE, 1999.

Sigmund, E. et al. Vztah mezi pohybovou aktivitou a inaktivitou rodičů a jejich 8-13letých dětí. Tělesná Kultura, 2008, 31(2), 89-101.

Suchomel, A. (2006). Tělesně nezdatné děti školního věku. Technická univerzita v Liberci, Pedagogická fakulta, Katedra tělesné výchovy a sportu, Liberec, str. 18, 26, 31. 
Vignerová, J., Bláha, P. Sledování růstu českých dètí a dospívajících. Norma, vyhublost, obezita. Praha: SZÚ, 2001.

Voss, L.D. et al. Children From Low-Income Families Have Less Access to Sports Facilities, But Are No Less Physical Active: Cross-Sectional Study. Health and Development, 2008, 34(4), pp. 470-474.

WHO. (2016). Obesity and overweight [on-line]. Posledná aktualizácia jún 2016, citované [2017- 04-28]. Dostupné z WWW: http://www.who.int/mediacentre/factsheets/fs311/en/.

\section{Kontaktné údaje:}

Mgr. Tomáš Hadžega

FTVS UK, Laboratoř sportovní motoriky

José Martího 269/31

16252 Praha 6 - Veleslavín, Česká republika

hadzega.tomas@gmail.com 